\title{
Rancang Bangun Aplikasi Pembelajaran Untuk Anak Umur 6 - 9 Tahun Berbasis Android
}

\author{
Iwayan S. A. Mukti, Arie S. M. Lumenta, Brave A. Sugiarso. \\ Program Studi Teknik Informatika, Fakultas Teknik, Universitas Sam Ratulangi \\ Email : adhi3693@gmail.com, al@unsrat.ac.id, brave.sugiarso@yahoo.com
}

\begin{abstract}
Abstrak - Bahasa inggris merupakan bahasa international yang kerap digunakan diberbagai bidang, misalnya dibidang pendidikan. Pengetahuan tentang bahasa inggris sudah diajarkan sejak dari sekolah dasar, tetapi tidak banyak dari anak - anak terlebih khusus anak usia 6 - 9 tahun untuk mudah mengerti tentang pengetahuan bahasa inggris. Terkadang orang tua rela mengeluarkan uang lebih untuk memberikan pelajaran khusus diluar sekolah seperti kursus untuk memberikan pengetahuan lebih tentang bahasa inggris kepada anak mereka. Pada perkembangan teknologi informatika terlebih khususnya pada teknologi smartphone yang bersistem operasi android telah banyak menyediakan beberapa macam aplikasi yang bisa mempermudah pekerjaan manusia sehari - hari. Tetapi banyaknya aplikasi yang beredar sekarang lebih didominasi oleh aplikasi yang diperuntukan kepada orang dewasa, sedangkan aplikasi yang dikhususkan untuk anak usia 6 - 9 tahun masih tergolong sedikit dan materi edukasinya terbatas dalam bidang pendidikan khususnya aplikasi pembalajaran bahasa inggris. Tujuan penelitian ini adalah untuk merancang dan membangun aplikasi pembelajaran bahasa inggris untuk anak usia 6 - 9 tahun yang menarik, interaktif dan mampu memberikan pengetahuan lebih tentang bahasa inggris. Aplikasi ini berbasis android dengan menggunakan metodologi Multimedia Development Life Cycle. Tahapan pada metodologi multimedia antara lain concept, design, material collecting, assembl, testing, dan distribution. Aplikasi pembelajaran yang dihasilkan mampu memberikan tambahan pengetahuan materi pembelajaran bahasa inggris dan mampu digunakan dengan baik oleh anak usia 6 - 9 tahun dengan syarat harus dibimbing oleh orang tua pada awal penggunaan aplikasi.
\end{abstract}

Kata kunci -Bahasa inggris, Aplikasi Pembelajaran, Multimedia, Android

\section{PENDAHULUAN}

Perkembangan teknologi Informatika dalam media elektronik seperti Handphone atau telephone genggam yang memiliki banyak fungsi yang dapat mempermudah pekerjaan manusia sehari- hari yang biasa disebut smartphone yang semakin hari semakin berkembang. Penggunaan smartphone di jaman sekarang sudah tidak mengenal umur lagi, dari kalangan orang tua sampai anak-anak sekarang sudah bisa menggunakan smartphone. Dalam penggunaan smartphone untuk kalangan anak-anak khususnya untuk anak umur $6-9$ tahun sekarang sudah semakin banyak, dikarenakan sejak balita orang tua mereka sudah membiasakan anak mereka menggunakan smartphone dengan platform android.
Dalam pengenalan huruf atau alphabet kepada anak umur $6-9$ tahun, orang tua sering kali hanya mengajarkan anak mereka dengan bahasa Indonesia, sedangkan bahasa inggris juga sangatlah penting di ajarkan sejak dini untuk anak umur 6 - 9 tahun. Pentingnya pengetahuan bahasa inggris dikarenakan, bahasa inggris adalah bahasa international yang wajib di pelajari di tiap negara.

Menurut IDC (International Data Corporation. Aplikasi yang banyak beredar saat ini didominasi oleh aplikasi yang diperuntukkan kepada orang dewasa, sedangkan aplikasi yang bermanfaat dan ditujukan khusus untuk anak usia dini masih tergolong sedikit, dan materi edukasinya masih terbatas. Dengan memanfaatkan banyaknya pengguna yang menggunakan platform android saat ini di kalangan anak - anak, pengguna mencoba untuk membuat aplikasi pembelajaran bahasa inggris yang berisikan cara penulisan huruf serta pengenalan kata-kata dalam bahasa inggris dengan metode yang lebih menarik.

\section{A. Alphabet}

\section{LANDASAN TEORI}

Menurut Surianto (2010), alphabet adalah suatu set huruf yang digunakan dalam bahasa tulisan. Alphabet pertama kali ada sekitar abad 17 sampai 15 sebelum masehi. Alphabet latin seperti yang digunakan dalam bahasa Indonesia dan inggris, menggunakan 26 huruf yang terdiri dari 21 consonants (huruf mati) dan 5 vowels (huruf hidup).

\section{B. Bahasa Inggris}

Menurut Shobirin (2008), bahasa inggris merupakan bahasa international yang kerap digunakan di berbagai bidang, misalnya bidang pendidikan. Bahasa inggris sudah dimasukan ke dalam kurikulum pendidikan nasional, bahkan jenjang pendidikan pra-sekolah (sebelum TK) menggunakannya. Banyak lembaga prasekolah mengenalkan Bahasa Inggris kepada anak didik sebagai bahasa keseharian di dalam lingkungan sekolah.

\section{Aplikasi}

Menurut Maryono (2008) perangkat lunak aplikasi merupakan program yang dikembangkan untuk memenuhi kebutuhan pengguna dalam menjalankan pekerjaan tertentu. Perangkat lunak aplikasi dibedakan menjadi beberapa macam berdasarkan kegunaannya. 


\section{Aplikasi Pembelajaran Interaktif}

Menurut Supriyanto (2005 : 117) aplikasi adalah program yang memiliki aktivitas pemrosesan perintah yang diperlukan untuk melaksanakan permintaan pengguna dengan tujuan tertentu. Sedangkan menurut Janner (2006 : 22) aplikasi adalah program atau sekelompok program yang dirancang untuk digunakan oleh pengguna akhir (end user). Aplikasi dapat dimanfaatkan untuk keperluan pembelajaran kepada siswa mengingat dalam suatu proses pembelajaran seharusnya terdapat interaksi antar komponen-komponen pembelajaran. Salah satu pendekatan pembelajaran yang memungkinkan antara komponen-komponen pembelajaran tersebut adalah pembelajaran interaktif. Menurut Hake (Veronica Cahyadi, 2003), pembelajaran interaktif adalah lawan dari pembelajaran tradisional yaitu elemen yang disusun untuk meningkatkan pemahaman konsep secara interaktif dari siswa melalui kegiatan berpikir dan bekerja yang menghasilkan umpan balik melalui diskusi dengan petunjuk atau tanpa petunjuk dari pendidik (guru).

Berdasarkan uraian di atas, dapat disimpulkan bahwa aplikasi pembelajaran interaktif adalah suatu program yang mengemas sebuah metode pembelajaran berbantuan komputer yang dapat memberikan respon balik terhadap pengguna akhir (siswa) dari apa yang telah diinputkan kepada aplikasi tersebut.

\section{E. Android}

Menurut wahana komputer (2013), android adalah nama sebuah sistem operasi berbasi linux yang ditujukan untuk perangkat bergerak dengan layar sentuh seperti smartphone dan komputer tablet. Awalnya android dibuat oleh perusahan android Inc. sampai akhirnya diakusisi oleh google pada tahun 2005. Berkat google, kini android semakin popular, terlebih lisensi yang digunakan adalah lisensi open source. Ikon android juga cukup terkenal, yaitu sebuah robot berwarna hijau.

\section{F. Metodologi Multimedia Development Life Cycle}

Menurut Vaughan (2011), multimedia adalah kombinasi dari teks, foto, seni grafis, suara, animasi dan video yang dimanipulasi secara digital dan disampaikan melalui komputer atau alat elektronik lainnya.

Menurut Binanto (2010) yang dikutip dari Luther (1994), metodologi pengembangan multimedia terdiri dari enam tahap, yaitu concept (pengonsepan), design (pendesainan), material collecting (pengumpulan materi), assembly (pembuatan), testing (pengujian), dan distribution (pendistribusian). Keenam tahap ini tidak harus berurutan dalam praktiknya, tahap-tahap tersebut dapat saling bertukar posisi. Meskipun begitu, tahap concept memang harus menjadi hal yang pertama kali dikerjakan. Berikut ini adalah gambar struktur metodologi multimedia yang bisa dilihat pada gambar 1 dan penjelasan tentang tahapan - tahapan dari konsep multimedia.

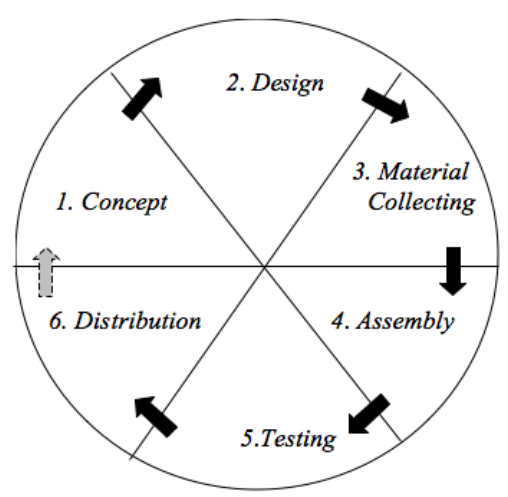

Gambar 1. Metodologi Pengembangan Multimedia

\section{Concept}

Tahap concept adalah tahap untuk menentukan tujuan dan siapa pengguna program

\section{Design}

Design adalah tahap pembuatan spesifikasi mengenai arsitektur program, gaya, tampilan, dan kebutuhan material/bahan untuk program.

\section{Material Collecting}

Tahap ini adalah pengumpulan bahan sesuai dengan kebutuhan yang dikerjakan. Bahan-bahan tersebut, antara lain gambar clip art, foto, animasi, video, audio, dan lain-lain yang diperoleh secara gratis atau dengan pemesanan kepada pihak lain sesuai dengan rancangannya.

\section{Assembly}

Tahap assembly adalah tahap pembuatan semua objek atau bahan multimedia.

\section{Testing}

Tahap Testing dilakukan setelah menyelesaikan tahap pembuatan (assembly) dengan menjalankan aplikasi/program dan melihatnya apakah ada kesalahan atau tidak.

\section{Distribution}

Pada tahap ini, aplikasi akan disimpan dalam suatu media penyimpanan. Jika media penyimpanan tidak cukup untuk menampung aplikasinya, kompresi terhadap aplikasi tersebut akan dilakukan. Tahap ini juga disebut tahap evaluasi untuk pengembangan produk yang sudah jadi supaya lebih baik.

\section{A. Concept \\ III. METODOLOGI PENELITIAN \\ Pada tahap ini, dilakukan kunjungan ke sekolah} dasar dan melakukan studi literature tentang aplikasi aplikasi serupa,untuk mendapatkan konsep yang sesuai untuk membangun aplikasi pembelajaran. 


\section{B. Material Collecting}

Tahap pengumpulan data ini dilakukan dengan menggunakan beberapa metode pengumupulan data, yaitu :

\section{- Analisa Kebutuhan Data Primer}

Dalam analisa kebutuhan data primer ini, peneliti melakukan observasi untuk mengambil data informasi di sekolah dasar negri 124 Manado.

\section{- Analisa Kebutuhan Data Sekunder}

Berdasarkan analisis kebutuhan data sekunder, peneliti membuat dan mengambil beberapa konten multimedia seperti gambar animasi, teks bahasa inggris, audio dan video visual yang dipadukan dalam sebuah aplikasi pembelajaran anak yang sesuai dengan kriteria atau karakter anak - anak berumur 6-9 tahun.

\section{Design}

Pada tahap design, peneliti membuat beberapa diagram seperti use case diagram, activity diagram, dan class diagram untuk membuat spesifikasi mengenai arsitektur program, gaya, tampilan, dan kebutuhan material/bahan untuk program.

\section{- Use Case Diagram}

Pada use case diagram ini peneliti menampilkan pemodelan dari aplikasi yang akan dibangun dimana user dapat mengakses beberapa fitur yang disediakan pada aplikasi. Pada pemodelan ini user atau pengguna dapat melihat tampilan awal, melihat informasi cara penggunaan dan memulai memainkan aplikasi. Dalam memulai memainkan aplikasi user dapat memulai tahapan - tahapan atau urutan permaianan yang dimulai dari memilih gambar animasi, kemudian menginput pola sesuai karakter, dan bisa melihat gambar animasi sesuai karakter yang dipilih yang bisa dilihat pada gambar 2 .

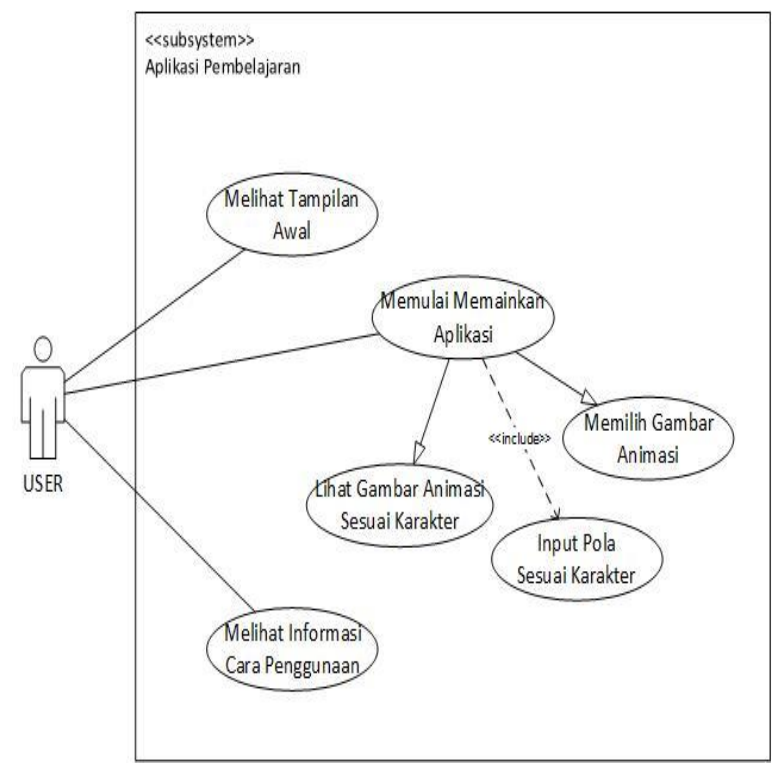

Gambar 2. Use Case Diagram Aplikasi Pembelajaran

\section{- Activity Diagram}

Activity Diagram Aplikasi Pembelajaran Anak bermaksud untuk menujukan urutan aktivitas dalam menjalankan atau mengoprasikan aplikasi pembelajaran anak. Aktivitas dilakukan dimulai dari pengguna atau user yang memilih fitur Help kemudian di respon oleh aplikasi untuk memberikan informasi tentang cara atau tutorial penggunaan aplikasi. Setelah itu pengguna atau user memilih fitur Let's Start untuk memulai permainan menyusun huruf demi huruf untuk membentuk suatu kata berbahasa inggris dan di respon oleh aplikasi. Untuk mmenampilkan hasil teks atau karakter gambar animasi yang dipilih user yang bisa dilihat pada gambar 3 .

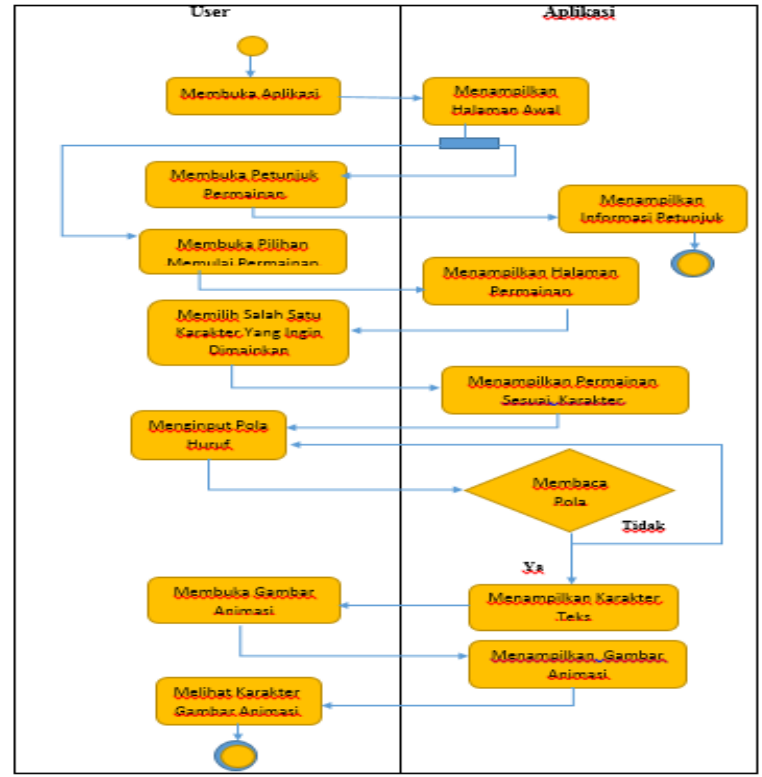

Gambar 3. Activity Diagram Aplikasi Pembelajaran

\section{- Class Diagram}

Class Diagram bersifat statis tetapi sering pula memuat Class aktif dan memperlihatkan himpunan Class atau relasi - relasi. Seperti pada gambar 3.7 class diagram aplikasi pembelajarana yang terdiri dari 5 kelas yaitu Class Mulai, Help, Pilih_Kata, Canvas1, dan Hasil yang memiliki variable dan method yang berbeda - beda sesuai fungsi dari setiap class yang bisa dilihat pada gambar 4.

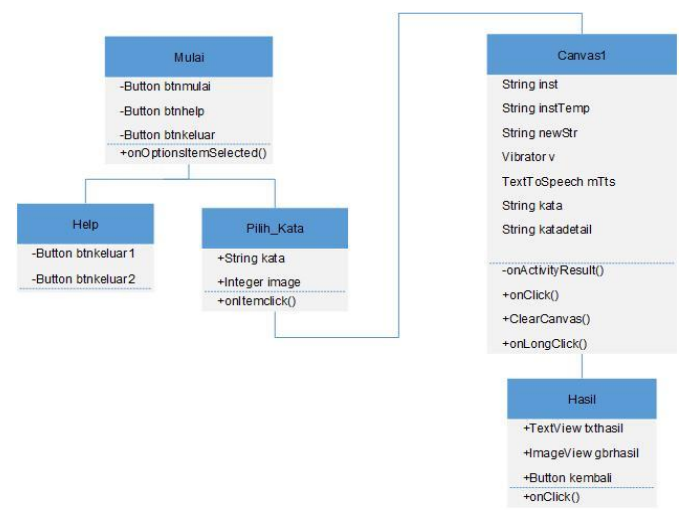

Gambar 4. Class Diagram Aplikasi Pembelajaran 


\section{A. Assembly}

\section{HASIL}

Dalam pembuatan aplikasi pembelajaran anak ini, peneliti menggunakan aplikasi eclipse untuk membangun aplikasi yang bisa berinteraksi dengan user atau pengguna yang di khususkan untuk anak usia 6 - 9 tahun dengan menggunakan beberapa fitur pendukung pada android yaitu text to speech yang merupakan modul audio yang dapat membaca teks dan menghasilkan output audio sesuai teks yang diberikan dan Handwriting recognition yang merupakan papan menulis pada android untuk memasukkan informasi melalui tulisan tangan ke dalam Handphone.

\section{B. Testing}

Pada tahap ini peneliti meenguji aplikasi yang telah dibuat dengan menampilkan beberapa tampilan aplikasi yang sudah dibangun.

\section{Membuka Aplikasi}

Gambar 5 menunjukan tampilan awal aplikasi, dimana pada tampilan ini peneliti memberikan latar tampilan gambar animasi ikan dengan huruf - huruf yang ada pada tubuhnya yang dimaksudkan agar anak - anak tertarik ketika melihat tampilan awal aplikasi. Pada tampilan ini aplikasi memberikan beberapa tombol seperti let,s start untuk memulai memainkan aplikasi pada anak panah nomor 1, help untuk melihat informasi cara penggunaan aplikasi pada anak panah nomor 2, exit untuk keluar dari aplikasi pada anak panah nomor 3 .

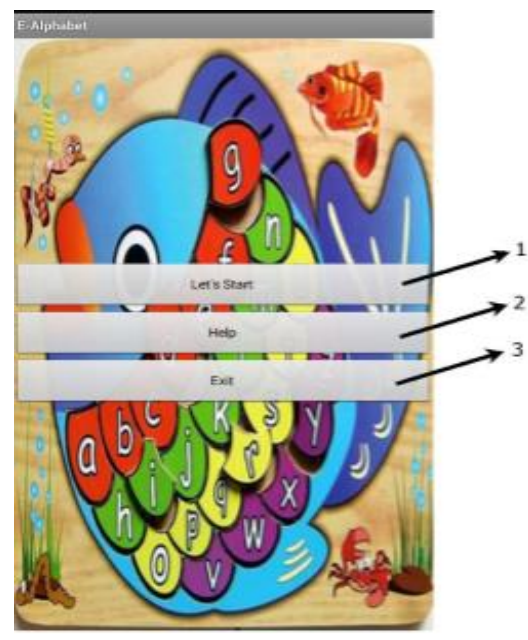

Gambar 5 Tampilan Awal Aplikasi

\section{Tampilan Menu Help}

Gambar 6 merupakan tampilan help atau petunjuk cara penggunaan aplikasi, dalam tampilan ini disediakan tombol back untuk kembali pada tampilan awal pada anak panah nomor 1, scroll untuk mengatur naik turunkan tampilan informasi pada anak panah nomor 2, dan penjelasan cara penggunaan pada anak panah nomor 3 .

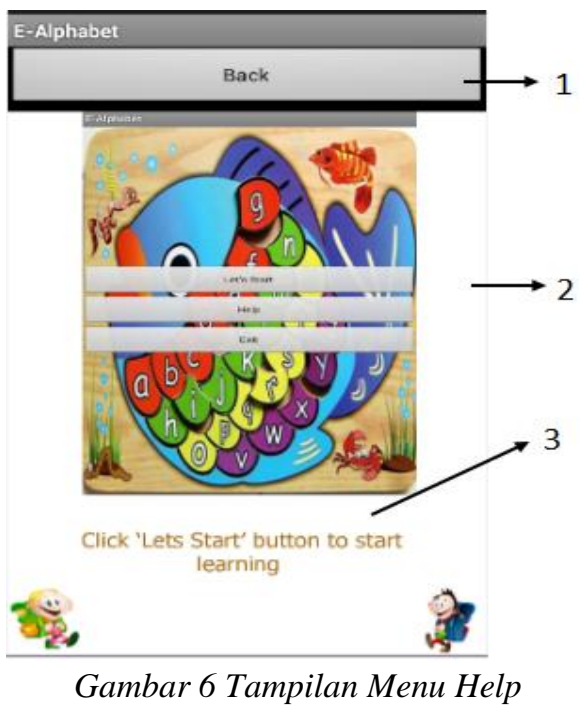

\section{Tampilan Menu List}

Gambar 7 merupakan tampilan list atau daftar dari karakter yang akan dipilih pengguna untuk dipelajari atau dimainkan. Pada tampilan ini peneliti memberikan warna biru muda agar terlihat lebih cerah dan menarik perhatian anak - anak yang ada pada anak panah nomor 2. Pada anak panah nomor 1 merupakan salah satu karater gambar animasi yang sengaja dibuat animasi karena karakter anak - anak yang menyukai animasi. Pada anak panah nomor 3 disediakan tombol back untuk kembali ke tampilan awal aplikasi.

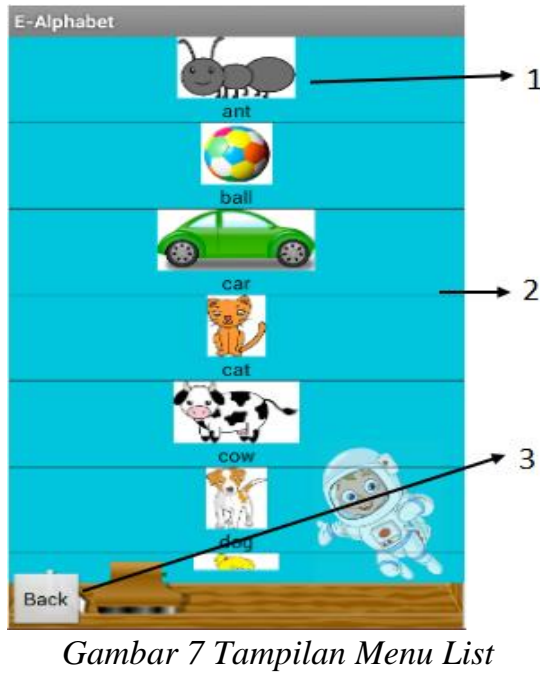

\section{Tampilan Proses Pembelajaran}

Gambar 8 merupakan tampilan dari proses pembelajaran yang telah di pilih dari tampilan list. Pada tampilan ini pengguna atau user di haruskan mengikuti animasi huruf bergerak yang ada pada anak panah nomor 3 untuk menulis pola huruf pada papan menulis pada anroid pada anak panah nomor 2 atau handwriting recognition sesuai demonstrasi dari gambar bergerak yang di tampilkan pada anak panah nomor 1. Tampilan warna yang diberikan pada halaman ini adalah perpaduan antara warna coklat muda dan putih yang dimaksudkan agar supaya anak - anak bisa melihat tampilan huruf dan animasi bergerak lebih jelas dan simple. 


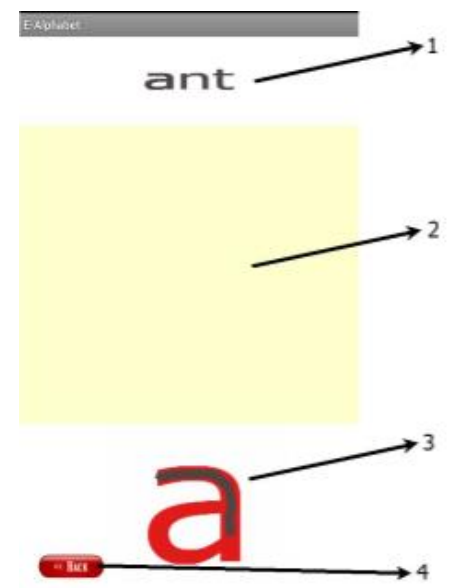

Gambar 8 Tampilan Proses Pembelajaran

\section{Tampilan Hasil Teks Karakter}

Gambar 9 merupakan tampilan hasil Teks dari karakter yang selesai di susun oleh pengguna. Tampilan dari hasil teks sengaja diberikan warna merah agar anak anak bisa mengetahui teks yang disusun telah berhasil diselesaikan seperti pada anak panah nomor 1 . Kemudian pada anak panah nomor 2 diberikan tombol untuk melihat gambar dari animasi teks yang telah selesai mereka susun dan tombol back untuk kembali ke tampilan menu list pada gambar 7 jika tidak ingin melihat gambar animasi karakter yang telah selesai disusun pada anak panah nomor 3 .

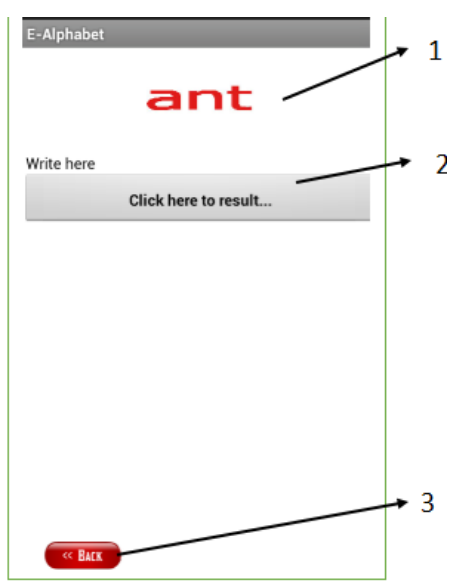

Gambar 9 Tampilan Hasil Teks Karakter

\section{Tampilan Hasil Gambar Karakter}

Gambar 10 merupakan tampilan hasil gambar animasi yang sesuai karakter yang telah di mainkan oleh pengguna atau user. Tampilan ini menampikan gambar animasi beserta teks penghargaan atau apresiasi dan juga pesan suara tepuk tangan agar supaya anak - anak merasa senang ketika menyelesaikan memainkan aplikasi pembelajara yang ada pada anak panah nomor 1 . Tampilan ini juga menyediakan tombol next untuk kembali memilih permainan yang lain pada tampilan gambar 7 pada anak panah nomor 2 .

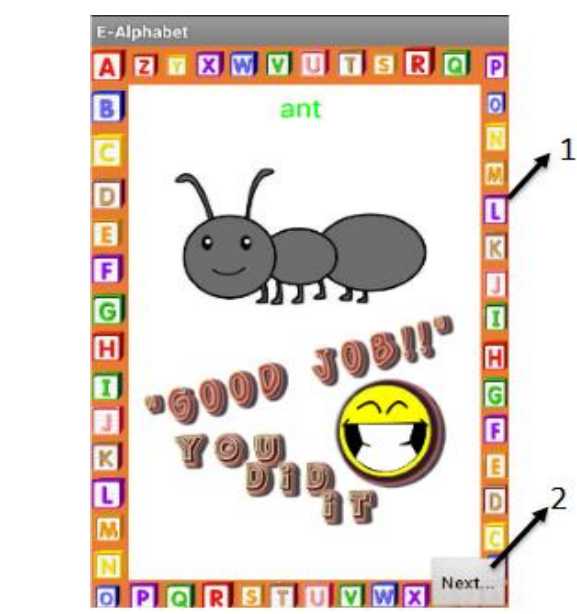

Gambar 10 Tampilan Hasil Gambar Karakter

\section{Evaluasi}

Setelah melakukan pengujian pada aplikasi selanjutnya peneliti melakukan evaluasi untuk menguji penggunaan aplikasi pada target penelitian yaitu anak umur 6-9 tahun. Pada evaluasi ini peneliti membagikan 20 kuesioner evaluasi yang bertujuan untuk mendapatkan tanggapan dan kesimpulan tentang aplikasi yang telah dibangun. Berikut ini merupakan salah satu tabel hasil evaluasi tentang tanggapan anak - anak dalam ketertarikan penggunaan aplikasi. Dari 20 kuesioner yang dibagikan, semua anak merasa tertarik untuk menggunakan aplikasi yang bisa dilihat pada tabel 1 .

Tabel 1. Tabel Hasil Evaluasi Ketertarikan

\begin{tabular}{|c|c|c|}
\hline Pilihan & Responden & Presentase \\
\hline Ya & 20 & $100 \%$ \\
\hline Tidak & 0 & $0 \%$ \\
\hline Jumlah & $\mathbf{2 0}$ & $\mathbf{1 0 0 \%}$ \\
\hline
\end{tabular}

\section{PENUTP}

\section{A. Kesimpulan}

Berdasarkan penelitian yang telah dilakukan, diperoleh kesimpulan sebagai berikut:

1. Aplikasi pembelajaran anak berfungsi dengan baik, semua fitur yang digunakan seperti Text To Speech, Handwriting Recognition, audio, gambar animasi, dan tampilan - tampilan semuanya berfungsi dengan baik.

2. Aplikasi pembelajaran memberikan tambahan pengetahuan bahasa inggris dan memberikan alternatife pembelajaran yang berbeda kepada anak umur 6-9.

3. Anak - anak mampu menggunakan aplikasi pembelajaran dengan baik dan juga anak - anak terlihat senang dan tertarik memainkan aplikasi pembelajaran dengan bimbingan orang tua pada awal penggunaan aplikasi. 
B. Saran

1. Diharapkan ke depannya aplikasi ini dapat memberikan pembelajaran dengan menggunakan tingkatan pembelajaran, agar supaya anak - anak bisa mendapatkan pembelajaran yang lebih tinggi dan bertahap.

2. Dalam Segi informasi pengetahuan yang diberikan, masih belum terlalu banyak pilihan, oleh karena itu diharapkan informasi pengetahuan yang ditampilkan bisa lebih banyak dan lebih bervariasi.

\section{DAFTAR PUSTAKA}

[1] Surianto R. (2010) Font \& Tipografi. Jakarta: PT. Gramedia.

[2] Shobirin R. (2008) Cara Mudah Belajar Basic English Grammar. Jakarta: PT. Tangga Pustaka.

[3] Maryono Y. (2008) Teknologi Informasi Dan Komunikasi. Jakarta: Yudhistira.

[4] Rizkiansah I. (2013) Pengembangan Aplikasi Pembelajaran Interaktif Teknik Bermain Piano Berbasis Multimedia Di Lembaga Kursus Musik “Ethnictro” Yogyakarta. Skripsi. Universitas Negri Yogyakarta. Tidak diterbitkan.

[5] Vaughan T. (2011) Multimedia: Making It Work (edn $\left.8^{\text {th }}\right)$. New York: McGraw-Hill.

[6] Binanto I. (2010). Media Digital-Dasar Teori dan Pengembangannya. Yogyakarta: C.V Andi.

[7] Wahana Komputer (2013) Kupas Tuntas Aplikasi Android Bagi Penggila Traveling. Yogyakarta: C.V Andi

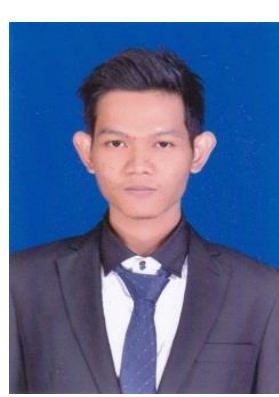

Penulis bernama lengkap Iwayan Suasta Adhi Mukti, anak keempat dari empat bersaudara. Lahir di Manado, Sulawesi Utara, pada tanggal 3 Desember 1993. Dengan alamat tempat tinggal sekarang di Jalan Sea, Kota Manado.

Penulis memulai pendidikan sekolah dasar diSD Negri 124 Manado (1998 - 2004), kemudian melanjutkan pendidikan tingkat pertama diSMP Negeri 8 Manado (2004 - 2007) dan melanjutkan pendidikan tingkat atas diSMK Negeri 1 Manado (2007 - 2010).

Pada tahun 2010, Penulis melanjutkan studi di Fakultas Teknik, Jurusan Elektro, Program Studi Informatika Universitas Sam Ratulangi Manado. Selama masa studi, Penulis tergabung dalam organisasi Himpunan Mahasiswa Elektro (HME).

Pada tahun 2014, penulis mengajukan proposal tugas akhir untuk penyelesaian studi S1 dengan judul penelitian Rancangan Bangun Aplikasi Pembelajaran Untuk Anak Umur 6 - 9 Tahun Berbasis Android dengan Studi Kasus SD Negri 124 Manado. Selama penelitian, penulis mendapatkan bimbingan dari Arie S. M. Lumenta, ST., MT. sebagai Dosen Pembimbing I dan Brave A. Sugiarso, ST., MT. sebagai Dosen Pembimbing II. Proses penyelesaian tugas akhir berlangsung selama 12 bulan hingga pada tanggal 19 Januari 2016 penulis resmi lulus di Teknik Informatika Universitas Sam Ratulangi dan menyandang gelar sebagai Sarjana Komputer. 